\title{
Educational enlightenment of L.N. Tolstoy's pedagogy
}

\author{
Irina S. Danilova ${ }^{1 *}$,Elena Y. Orekhova ${ }^{2}$, and Nadezhda A. Shaidenko ${ }^{3}$ \\ ${ }^{1}$ Tula State Lev Tolstoy Pedagogical University, Latin Languages Department, Tula, Russia \\ ${ }^{2}$ Moscow City University, Institute of Foreign Languages, Department of French Language and \\ Linguodidactics, Moscow, Russia \\ ${ }^{3}$ The Advanced Training and Professional Retraining Institute of the Education Professionals of Tula \\ Region, Center for the Strategic Planning of the Education Development, Expertise and Scientific \\ Advice, Tula, Russia
}

\begin{abstract}
The reality of the modern educational environment and the development of the humanitarian, pedagogical knowledge about the environment are attributed to the experience of great minds of the past. Among them, L.N. Tolstoy's personality and versatile heritage have amazed and inspired numerous pedagogical generations to come through the writer's unparalleled educational ideas on the creation of popular (mass) schools. Just as Tolstoy's educational ideas and experience are enriched by the legacy of French enlighteners, the authors axiologically actualize and rethink through the prism of modern education the pedagogical heritage and arguments that ensure the broad perception of educational problems and the understanding of the continuing mission and driving force of education for the transformation of modern society. In the context of the priority of the humanistic educational paradigm, the authors are convinced that the interaction presented in the article through the imaginary dialogue of generations of Russian and foreign teachers of the present and the past contributes to the growth of professional knowledge in the field of the history of pedagogy and education and comparative pedagogical studies. It unites people involved in today's education, representatives of different socio- and linguistic cultures, in striving towards enlightenment in the best traditions of Tolstoy's education.
\end{abstract}

Keywords: enlightenment, L.N. Tolstoy's pedagogy, comparative pedagogical studies, education.

\section{Introduction}

"What reasons has the school of our day to teach this, and not that, thus, and not otherwise? Always and in all ages humanity has endeavoured to give and has given more or less satisfactory answers to these questions, and in our time this answer is even more necessary than ever" [1]. L.N. Tolstoy's words are even more relevant today, in an era of global uncertainty, when a civilization devoid of any value, moral, and spiritual orienting points is plunged into a steep dive, the exit from which is in no way conditioned or guaranteed by

\footnotetext{
* Corresponding author: danilovais@yandex.ru
} 
anyone. Modern pedagogy, traditionally based on dialogicality, textuality, and humanistic discourse, is being tested for strength both in the field of preserving traditions and engaging in innovations. Researchers from different countries unwaveringly discuss and predict the future of education [2-4]. The prospects for the productive future of education are formed, in which knowledge and learning are viewed as "humanity's greatest renewable resources for responding to challenges and inventing alternatives. Yet, education does more than respond to a changing world. Education transforms the world" [5]. In search of opportunities for transformation and creation, first of all, mass (school) education, pedagogical discourse has been uniting many generations of scholars, educators, and thinkers - enlightened people of their eras [6-8] for more than a decade or even centuries. Tolstoy's personality as a great enlightener of Russia and the vitality of the writer's pedagogical heritage surprise everyone - teachers, fellow countrymen and compatriots, as well as foreign colleagues, with farsightedness and sharp pedagogical intuition.

\subsection{Research problem}

Time demands and dictates a methodological renewal to modern pedagogy and educational science. This is especially noticeable within the framework of comparative pedagogical studies. We propose to extract fragments of new scientific knowledge for pedagogical comparative research from an anthropological source. The approach is not new. However, no matter the reasons through which the scientific search is objectified in comparative pedagogy, by the measure of a great personality (in this work -Tolstoy's personality), it is possible to measure those spiritual orienting points and cultural preferences that determine pedagogical landmarks for centuries. They become the object of comparative research. It is productive to distinguish and subdivide the personality with bearers of consciousness, similar synchronically and diachronically.

\subsection{The goals of the study}

The following research goals were set:

- to axiologically actualize and reconstruct the key ideas of Tolstoy's pedagogical views through the prism of the ideas of the French enlightenment, which so deeply and paradoxically influenced Tolstoy's personality and worldview as an enlightener of the era;

- to emphasize the problems, the realism of which we observe in modern mass (school) education in Tolstoy's pedagogical heritage.

The topic of the study is the address to Tolstoy's personality. It does not require any additional characteristics but multilaterally, interculturally, and interdisciplinary links the research of scholars around the world in reflections on education, defining educational guidelines for centuries.

\section{Methods}

The following methods were applied during the study:

- the biographical method, not so much chronological as axiological, dictated by the works and actions of the studied personalities, made it possible to compositionally present the reasoning in the form of an imaginary dialogue and polylogue and revive the traditional research algorithm of comparative pedagogical research;

- a critical analysis of the historical and pedagogical literature and Tolstoy's original works contributed to the concretization of the basic concepts that reflect the individuality and 
significance of the person in the era;

- the method of implicit comparison launched the mechanisms of searching for the familiar and foreign in the pedagogical reflections of individuals of Russian and Western cultures, united by the phenomenon of Tolstoy and the writer's teaching.

\section{Results and discussion}

1. Through time we start the dialogue with Tolstoy, which the writer considered a necessary way of cognizing the spiritual and value foundations of being, to illuminate those sources that contributed to the spirit of awakening Tolstoy's pedagogical creativity and shaped him as a thinker, teacher, and educator.

"Rousseau has been my teacher since I was fifteen years old... Rousseau does not grow old. ... I experienced the same sentiment of elevation of soul and admiration that I experienced in my youth" [9]. It is understandable that from his youth Tolstoy, like entire generations of Russian society in the past, came under the spiritual influence of France and its enlighteners who united the progressive people of both countries in various fields of humanitarian knowledge, including in reflections on education, understanding its essence and the surrounding social context.

2. The humanistic nature and orientation towards the people, as the spiritual heritage of the educational views of F. Rabelais, M. de Montaigne, and Jean-Jacques Rousseau, was carried and preserved by Tolstoy - "a dreamer in pedagogy" [10] - throughout the creative life: in active work to create an original system of education and upbringing of children of the Russian peasantry, the arrangement of the Yasnaya Polyana school, and the interpretation of the structure of public education in Russia. Like the French enlighteners, absorbing the voices of individuals and eras, could Tolstoy be just a dreamer? We are convinced the educator could not. Tolstoy gave his heart full of ardent love to the Russian people, devoting himself to finding the best ways to enlighten them and create a true school for the people.

In the pedagogical work, Tolstoy did not only dream but tirelessly enlightened himself, being convinced that a good teacher must live well and correctly, not getting tired of selfeducation and self-improvement. Having the command of several foreign languages and European education, Tolstoy thoroughly approached everything that attracted his indefatigable nature in search of both related (similar) and nationally distinctive phenomena of educational reality. This determined the development of pedagogical thought in Russia and became part of educational heritage for future pedagogical generations.

Tolstoy's pedagogical intuition, formed as a result of the persistent study of the pedagogical works of Montaigne and Rousseau in the original, the like-minded predecessors, and trips abroad to study mass (school) education, contributed to the accumulation and growth of knowledge in the field of comparing the experience of teaching and upbringing in schools of European countries. Naturally, Tolstoy did not originate comparative pedagogy. However, the theoretical and practical information collected by the writer in the field of mass (school) education is the subject of comparative study and significantly enriches the history of pedagogy, humanitarian knowledge, and education in general [11-15].

3. "...education is history, and therefore has no final end. Education, in its widest sense, including the bringing up, is, in our opinion, that activity of man, which has for its base the need of equality, and the invariable law of educational progress" [1]. This reasoning by the educational philosopher Tolstoy illuminated the dreams and hopes of the free upbringing by Russian contemporaries K.D.Ushinsky and N.I. Pirogov [16], who shared Tolstoy's conviction that the Russian school had a unique formative path that should take shape according to the historical era and history of the country. The history of education was shaped by both Tolstoy the teacher and the subsequent generations of pedagogical followers, in whom Tolstoy's pedagogical doctrine ignited the sparks of pedagogical enlightenment. These 
like-minded individuals had professional and pedagogical striving for changes in education, personal motivation to be ahead of time in creating a new image of the school, due to which experience, freedom, rejection of violence, and love would become value dominants. From a historical perspective, we are familiar with the practical implementation of ideas about a new school and a new philosophy of education, expressed in the Russian [16-18] and foreign educational experience of modern time [19-22].

4. "The activity of him who gives the education and has one and the same purpose. The problem of the science of education is only the study of the conditions under which a coincidence of these two tendencies for one common end takes place..." [1]. Despite the decades and centuries that have passed, Tolstoy's conviction remains eternal. Especially now, when the new values of the global society are increasingly aggressively taking over the educational space, undermining the foundations of fundamental traditions, including those formed based on Tolstoy's educational ideas. Today's teachers must not lose these traditions. On the contrary, having preserved the best traditions in teaching and upbringing of the Yasnaya Polyana teacher, they can fill the existing gaps in the educational space and scientific knowledge of today with Tolstoy's pedagogical heritage.

The desire and involvement of "those who educate and those who are educated" (in Tolstoy's pedagogical concepts) in different contexts of education -scientific and pedagogical search and study, educational practice, and the socio-cultural aspect - will make it possible to determine ways to overcome the problematic field of modern educational space of mass (school) education. The questions of freedom of choice in education, individualization and personalization, individual educational trajectory, and personal freedom of the teacher and the student are urgent again [23-26]. These issues were also addressed by Tolstoy and promoted productive educational experiences but the writer never came to an absolute solution. However, Tolstoy accumulated pedagogical maxims, valuable and harmonious with modern time and education.

In the era of global challenges and transformations, everything is changing. However, the mass school in its basic components remains one of the most stable institutions of society which is so zealously and emotionally criticized by Tolstoy's predecessors, by the writer himself, and in modern reality. The paradox of the system's stability continues to excite the pedagogical thought of each new generation of teachers, for whom Tolstoy's pedagogical work continues to be a source of enlightenment of thinking people in different countries.

One such profound thinker is Michel Aucouturier, a French historian, translator, scholar, editor, and compiler of scientific collections, whose life interests were associated with Tolstoy. It is impossible to ignore this person, both in memory of his recent loss and in gratitude for the personal care and professional and educational activities for the preservation and dissemination of Tolstoy's (and not only, the entire Russian) heritage in other, including French, cultures. Aucouturier translated and wrote a lot about Tolstoy and revived the work of the Association of Tolstoy's Friends (l'Association des Amis de Tolstoï), including the publication of Cahiers Léon Tolstoï [27]. Aucouturier's work inspired by Tolstoy's works and personality is truly an experience of self-education and the path of enlightenment in the French academic and pedagogical field, about which the educator from Yasnaya Polyana wrote a lot.

We see some symbolism in Tolstoy's mutual communication with France, which determines the vitality of the teacher and thinker's educational enlightenment. Namely, the French enlighteners had a tremendous influence on the pedagogical thought of Tolstoy's epoch and Tolstoy's personality as a teacher and retain their meaning-making significance today. Similarly, the phenomenon of Tolstoy's personality and his pedagogical heritage is a source of enlightenment not only for Russian education but also for French and in general for education all over the world. 


\section{Conclusion}

In this work, we only managed to touch upon Tolstoy's personality and pedagogical heritage which has inexhaustible possibilities in the organization of education today. The timeliness and viability of Tolstoy's educational experience and ideas do not allow us to forget that the past always exists in the present in the shape of the embodied scientific heritage. They give understanding and cognition of true scientific knowledge, preventing fiction and substitutions from permeating science and education. This truth is proved by the chosen path of the enlightener Tolstoy and the writer's educational art in pedagogy and education. Tolstoy convinces the reader that the experience and great ideas of past generations contribute to the birth of creative and productive humanistic ideas on a truly global scale. The reflection of these ideas not only enriches them with value-based content but also contributes to the understanding of the reality of what is happening through the influence of enlightened individuals, reveals the worldview, including the world of science and education, and transforms the world with the light of enlightenment, creating prospects for a hopeful and bright future.

\section{References}

1. L.N. Tolstoy, Collected works: in 22 volumes, Volume 8, 4-25 (Khudozhestvennaya literatura, Moscow, 1936)

2. D. Labaree, The futures of the field of education, in G. Whitty, J. Furlong, (Eds.) Knowledge and the Study of Education: An International Exploration (Symposium Books, Oxford, 2017)

3. A. Schleicher, World Class: How to Build a $21^{\text {st }}$ Century School System, Strong Performers and Successful Reformers in Education (OECD Publishing, Paris, 2018). https://doi.org/10.1787/9789264300002-en

4. J. Edmonstone, A. Lawless, M. Pedler, Action Learning: Research and Practice, 16(1), 37-51 (2019). https://doi.org/10.1080/14767333.2019.1568967

5. UNESCO, The Futures of Education: Learning to Become report (2020). Accessed on: August 12, 2020. [Online]. Available: https://en.unesco.org/futuresofeducation/initiative

6. S. Lewis, Journal of Educational Policy, 32(3), 281-302 (2017). https://doi.org/10.1080/02680939.2016.1252855

7. I.S. Danilova, E.Ya. Orekhova, N.A. Shaidenko, The European Proceedings of Social \& Behavioural Sciences, 69, 267-276 (2019). https://doi.org/10.15405/epsbs.2019.09.02.32

8. H. Proctor, A. Roch, G. Breidenstein, M. Forsey, Comparative Education, 56(3), $317-$ 330 (2020). https://doi.org/10.1080/03050068.2020.1781422.

9. L.N. Tolstoy, Collected works: in 22 volumes, Vol. 20, 582 (Khudozhestvennaya literatura, Moscow, 1984)

10. L.N. Tolstoy v vospominaniyakh sovremennikov [L.N. Tolstoy in the contemporaries' memories] (Khudozhestvennaya literatura, Moscow, 1978)

11. I. Paperno, "Who, What Am I?": Tolstoy struggles to narrate the self (Cornell University Press, Ithaca, London, 2014)

12. F. Lesourd, Tolstoï et la vie intellectuelle de son temps. Cahiers Léon Tolstoï $n^{\circ} 26$ [Tolstoy and the intellectual life of his time. Leo Tolstoy Notebooks $n{ }^{\circ} 26$ ] (Institut d'Etudes Slaves, Paris, 2015) 
13. C. Delaunay, Lev Tolstoj lettore di scrittori e filosofi occidentali: fra indipendenza e appropriazione [Lev Tolstoy reader of writers and philosophers Western: between independence and appropriation], in C. Pieralli, C. Delaunay, E. Priadko (Eds.), Russia, Oriente slavo e Occidente europeo: fratture e integrazioni nella storia e nella civiltà letteraria [Russia, the Slavic East and the European West: fractures and integrations in literary history and civilization] (Firenze University Press, Firenze, 2017)

14. W. Berelowitch, Cahiers du monde russe, 59(1), 165-168 (2018). https://doi.org/10.4000/monderusse. 10334

15. N.V. Kudryavaya, Zhurnal narodnoe obrazovanie, 177-183 (2019)

16. V.B. Pomelov, Pedagogika. Voprosy teorii i praktiki. Tambov: Gramota, 2(10), 32-37 (2018) https://doi.org/10.30853/pedaqoqy.2018-2.7

17. N.P. Yudina, Istoriko-pedagogicheskii zhurnal, 3, 138-146 (2013)

18. V.B. Remizov, Uroki Tolstogo i shkola kultury. Kniga dlya roditelei i uchitelei [Tolstoy's lessons and the school of culture. The textbook for parents and teachers]. (RG-Press, Moscow, 2019)

19. O.M. Baryshnikova, Obrazovanie i nauka, 5(41), 117-123 (2006)

20. A. Philonenko, Le Philosophoire, 29(2), 143-163 (2007) https://doi.org/10.3917/phoir.029.0143

21. O. Bernaz, Revue philosophique de la France et de l'étranger, 142(3), 325-340 (2017) https://doi.org/10.3917/rphi.173.0325

22. A. Hamling, Contemporary Icons of Non violence (Cambridge Scholars Publishing, Cambridge, 2019)

23. T. Burns, F. Köster (Eds.), Governing Education in a Complex World (Educational Research and Innovation, OECD Publishing, Paris, 2016). https://doi.org/10.1787/9789264255364-en

24. J. Duke, H. Pillay, M. Tones, J. Nickerson, S. Carrington, A. Ioelu, Compare: A Journal of Comparative and International Education, 46(6), 906-928 (2016) https://dx.doi.org/10.1080/03057925.2016.1204226;

25. E.Ya. Orekhova, I.S. Danilova, N.A. Shaidenko, Contemporary Family in Sociocultural Environment, in EEIA-2018, 2018 International Conference "Education Environment for the Information Age", Moscow, Russia, 556-562 (2018). https://dx.doi.org/10.15405/epsbs.2018.09.02.64

26. J.-M. De Ketele, Revue internationale d'éducation de Sèvres, 83, 205-233 (2020). https://doi.org/10.4000/ries.9463

27. Cahiers Léon Tolstoï (L'institut d'études slaves, Paris, 1984-2020). Accessed on: December 20, 2020. [Online]. Available: http://institut-etudes-slaves.fr/tagged/clt/ 